\title{
ELLENTMONDÁSBAN? KÖZPONTI HELYEK ELMÉLETE ÉS A VÁROSOK SPECIALIZÁCIÓJA ${ }^{1}$
}

\author{
(Central Place Theory and the Specialisation of Cities: \\ a Contradiction?)
}

\author{
CZIRFUSZ MÁRTON
}

Kulcsszavak:

városfejlesztés központi helyek növekedési pólusok Németország Brandenburg

A tanulmány a központi helyek elméletét és a területfejlesztésben ezzel szembenálló, a városok specializálódása irányába ható irányzatokat (policentrikus városhálózat, növekedési pólusok) ütközteti a németországi Brandenburg tartomány példáján. A cikk rámutat arra, hogy a központi helyek elmélete a németországi tervezési gyakorlatban a rendszerváltozást követōen annak ellenére megmaradt, hogy az ällami szféra társadalmi és gazdasági folyamatokat meghatározó szerepe lényegesen csökkent. Emellett újonnan megjelentek olyan elemek, mint a növekedési pólusok fejlesztése, vagy városi szinten a városmarketing, a városok profilírozásának igénye. A városi szinten, mint a brandenburgi felsófokú központok integrált városfejlesztési koncepcióit elemzó fejezet bemutatja, ezek az egymásnak ellentmondó tervezési elméletek párhuzamosan vannak jelen, a hangsúlyokat pedig nagyrészt az egyes városok adottságai és egyéni érdekei határozzák meg.

\section{Bevezetés}

Napjainkban reneszánszukat élik a városhierarchia-vizsgálatok az európai és hazai elméleti kutatásokban, valamint kifejezetten a gyakorlati megfontolásokat szem előtt tartó területfejlesztésben. Utóbbi, uniós, nemzeti, regionális szinten írott dokumentumok az ellátott funkciók alapján sorolják be az egyes településeket különböző hierarchiaszintekbe, azaz homogenizálódás, adott szinten egymással megegyezö, de legalábbis nagyon hasonló funkciójú-szerepkörü központi helyek felé mozdítják a településállományt. Ugyanakkor napjaink városversenyében minden település (egy hierarchiaszinten belül különösen) egymás versenytársaként lép fel, ami a városi szintet vizsgálva a specializálódás irányába tolja el a városokat, a városfejlesztést és a városmarketinget. Ezt a szempontot erősítik tervezési oldalról a növekedési pólusokat preferáló, vagy a policentrizmust célként megfogalmazó irányzatok (például az Európai Területfejlesztési Perspektíva - European Commission 1999). A két irányzat elméleti oldalról tekintve szemben áll egymással, ám a gyakorlatban sokkal inkább együttélésükröl beszélhetünk.

A tanulmány, a németországi Brandenburg tartományt mintaterületként választva (ahol a városfejlesztési tervek jól definiált rendszere áll rendelkezésre, valamint amelynek városfejlesztési gyakorlata több ponton hasonlóságot mutat a magyarországi példával), az elméleti bevezető után ezen eltérő álláspontok, érdekek ütkö- 
Czirfusz Márton : Ellentmondásban? Központi helyek elmélete és a városok specializációja.

Tér és Társadalom 23. évf. 2009/3. 13-25. $p$.

14 Czirfusz Márton

TÉT XXIII. évf. 2009 - 3

zését elemzi különböző területi szinteken: a tartományi és az országos szintủ fejlesztési politikában, illetve az egyes városok fejlesztési terveiben. Áttekinti a tartományi területi tervezés vonatkozó dokumentumait, a városi szintü specializálódási/profilírozási stratégiákat pedig a hat felsőfokú központként definiált város integrált városfejlesztési stratégiájából fejti ki.

\section{Központi helyek elmélete: megközelitési módok és következmények}

A központi helyek egy olyan térgazdaságtani-társadalomföldrajzi elmélet, amely különbözỏ szolgáltató tevékenységek területi elhelyezkedését írja le és magyarázza meg. A klasszikus vizsgálatok arra voltak kíváncsiak, hogy döntően a piaci folyamatok révén hogyan valósul meg a társadalom ellátása különböző javakkal és szolgáltatásokkal.

A központi helyek elméletének elhelyezéséhez segítséget nyújt Faragó László (2007) tanulmánya, aki a településhálózat struktúrájának áttekintéséhez négy különbözỏ modellt vázol. Ezek közül a központi helyek rendszere alapesetben szigorú vertikális feladatmegosztáson nyugvó centripetális struktúrát fed, amelynél a szinteken belül nincsenek kooperációs kapcsolatok. Ha az egyes szinteken belül valamilyenfajta funkciómegosztás történik (szintenként kooperáló hierarchikus struktúra), a rendszer a specializálódás irányába mozdul el, és a központi helyek viszonylag merev rendszere oldódik.

A magyarországi és a nemzetközi vizsgálatok a későbbiekben rámutattak, hogy a városok közötti verseny növekedésével a klasszikus forgatókönyv (a nagyobb városok magasabb szintü funkciókat látnak el) és a hagyományos vonzáskörzet-rendszer felbomlik, a városok többnyire specializáltabbá válnak, a településállomány egyre nehezebben „hierarchizálható” kutatási szempontból (Beluszky 1985; Meijers-Romein 2003; Beluszky-Györi 2004; Markusen-Schrock 2006; Seelig 2007). Ugyanígy ágazatonként is különbségek lehetnek: a kiskereskedelemben például (fỏleg a nagy népsürüségü területeken) egymást átfedő-kiegészítő, kevésbé hierarchikusan szerveződő vonzáskörzetek alakulnak ki, melynek tervezésében és irányitásában a központi helyek elmélete kevés fogódzót ad (Koschny-Mensing-von Rohr 1998).

A központi helyek elméletét az 1960-as évektöl a területi tervezési gyakorlatba is átültették (Magyarországon ennek szellemében készült az 1971-es Országos Településhálózat-fejlesztési Koncepció), ebben az esetben viszont az elmélet egy irányítási modellé alakul át, melynek segitségével település-, gazdasági és infrastrukturális fejlesztést végeznek (Blotevogel 2005). Elsődleges szerepe, hogy az azonos funkciójú városok közötti egyenlötlenségeket csökkentse azáltal, hogy a hierarchikus szintekhez ellátandó feladatokat - funkciókat rendel (éppen ez hiányzott részben a magyar OTK-ból - Beluszky 1985). Ennek a modellnek a múködéséhez és müködtetéséhez „szükség volt” az állami szféra jelentős (sok esetben kizárólagos) szerepvállalására a lakosság ellátásában, amelynek igazi kísérleti laboratóriumát a szocialista tervgazdaságok adták. Ugyanakkor a rendszerváltozás után a tervekben 
Czirfusz Márton : Ellentmondásban? Központi helyek elmélete és a városok specializációja. Tér és Társadalom 23. évf. 2009/3. 13-25. p.

TÉT XXIII. évf. 2009 a 3 Ellentmondásban? 15

(és a fejekben) láthatólag továbbél a központi helyekhez való ragaszkodás, a piacivá vált folyamatok minél szélesebb körú irányításának vágya vagy az abba vetett hit. Az elméletet nem váltotta fel új teória, az újabb megközelítések a központi helyek mellé sorakoztak fel.

A tervezési gyakorlat kritikáit már a rendszerváltozás elött is felvetették, így többek között a központi helyek rendszerének túlságosan merev jellegét (például a városok specializálódása ellen ható voltát). Ehhez kapcsolódva az országos szinten gondolkozó elmélet nem keresett speciális megoldásokat a különleges településhálózati problémákra (Beluszky1985). A döntéshozás ráadásul igencsak direkt és centralizált maradt a mai napig, amelynek újraszabályozása is javasolt (Pálné Kovács 2008; Somlyódyné Pfeil 2008).

Természetesen az álláspontok az irányítással, szükebben a funkciómegosztással kapcsolatosan sem egyöntetủek. Stiens és Pick (1998) például azt vetik fel, hogy a szinteken belüli feladatmegosztás kontraproduktív és környezeti fenntarthatósága sem megfelelö, hiszen az „egy helyen elintézhetö” dolgok helyett bizonyos szolgáltatások igénybevételéért több településre szükséges elutazni, azaz nem valósul meg az utazási távolságok minimalizálása. A szerzők gondolatának hátterében áll egyrészt a központi helyek elméletének egyik, Johnston és Sidaway (2004) által hangsúlyozott alapja, vagyis, hogy az egyes személyek racionális gazdasági szereplők legalábbis az utazási költségek tekintetében; másrészt nem veszik figyelembe Beluszky Pál (1985) azon meglátását, hogy a településfunkciók megosztásával magasabb szintü funkciók ellátására is lehetőség nyilhat.

Összességében a reálfolyamatok szintjén a rendszer a Faragó-féle kategóriákat használva a szintenként kooperáló hierarchikus struktúra irányába mozdul el, ezzel szemben a tervezés és a tervek viszonylatában megmarad a szigorúan hierarchizált szerkezet. Sőt, a megnevezésekben a policentrikusságra hangsúlyt fektető magyarországi tervek egy része is valójában hierarchiákban gondolkozik: az új magyarországi településhálózat-fejlesztési koncepció megalapozását elősegitô tanulmány például alig foglalkozik magával a hálózattal (azaz a települések közötti kapcsolatokkal - fóleg azok nem jogi természetű oldalával és sokféleségével), sokkal inkább a területi különbségek összefoglalásával, vagy a települések/térségek hierarchikus szintekbe sorolásával (MTA RKK-VÁTI 2008).

\section{A brandenburgi gyakorlat}

Brandenburg tartományban (mint volt keletnémet országrészben) a központi helyek rendszere több évtizede erőteljesen jelen van a területfejlesztési gyakorlatban, amelyhez újonnan jelentek meg egyéb, a specializálódás irányába ható jegyek.

A tartományi kormányzat 1995-ben fogadta el a központi helyek ma érvényben levö rendszerét, amely szerint a tartomány ,településhálózata a központi helyek elveire alapozva fejlesztendö" (GLBB 2002, 2). Ezzel tervezéspolitikai nézőpontból továbbra is a hatvanas-hetvenes évek alapvetően felülröl irányított modelljét alkal- 
Czirfusz Márton : Ellentmondásban? Központi helyek elmélete és a városok specializációja.

Tér és Társadalom 23. évf. 2009/3. 13-25. $p$.

TÉT XXIII. évf. 2009

mazták (annak ellenére, hogy a központi helyek rendszerének kidolgozásába bevonták magukat a városokat), amely azon a tudományelméleti paradigmán is alapul, hogy a társadalmi változások tudományosan és objektíven tervezhetők (Seelig $2007)^{2}$. A kialakított többszintủ hierarchia - melynek szintjeihez hozzárendelték az általuk ellátandó funkciókat is (ebböl közöl egy részletet az 1. táblázat) - megkülönböztet egymástól felsőfokú, középfokú, alapfokú és kiscentrumokat; altípusként néhol megjelennek a részleges jelzővel kiegészített kategóriák, valamint azok a várospárok, amelyek együttesen látnak el bizonyos szintủ funkciókat. Ezzel az öszszetett nómenklatúrával ugyan a tervezők számára bonyolították a szerkezetet, viszont a rendszer merevségét is oldották, hiszen a részleges központok kategóriájával különbségeket „engedtek” azonos hierarchiaszintủ városok között.

A táblázat az ellátandó funkciókról jól példázza azt a tényt, hogy az állam az általa irányítani és befolyásolni képes ágazatokkal, intézményekkel képezi le a városhierarchiát. Valamennyi területen (az egyéb szolgáltatásokat kivéve) az állami (városi) tulajdon a domináns. Vagyis a központi helyek hierarchiája a brandenburgi felfogásban sem a piaci folyamatok és a piaci szereplők döntései révén alakul ki a települések között.

\section{TÁBLÁZAT}

Felsófokú központok ellátandó funkciói Brandenburg tartományban

(Providing Functions of High-level Centers in Brandenburg Province)

\begin{tabular}{|c|c|}
\hline Terület & Ellátandó funkciók \\
\hline Képzés/Ifjúság & $\begin{array}{l}\text { egyetemek, föiskolák, kisegítö iskolák, felsőfokú szakkép- } \\
\text { zési központok }\end{array}$ \\
\hline Kultúra & $\begin{array}{l}\text { színház, konferenciaközpont-koncertterem, múzeumok, } \\
\text { tudományos könyvtár }\end{array}$ \\
\hline Sport & $\begin{array}{l}\text { stadion lelátókkal, egyéb sportágakhoz szükséges létesít- } \\
\text { mények }\end{array}$ \\
\hline $\begin{array}{l}\text { Egészségügy, } \\
\text { Szociális ellátás }\end{array}$ & $\begin{array}{l}\text { súlyponti vagy általános ellátást adó kórház, speciális } \\
\text { klinikák, számos területen szakorvosi ellátás }\end{array}$ \\
\hline $\begin{array}{l}\text { Egyéb szolgálta- } \\
\text { tások }\end{array}$ & $\begin{array}{l}\text { áruház, speciális igényeket kiszolgáló bevásárlási lehetỏ- } \\
\text { ségek, nagyobb bankok és hitelintézetek }\end{array}$ \\
\hline Hatóságok & felső- ill. felsőbb szintủ tartományi hatóságok és bíróság \\
\hline Közlekedés & autópálya-csatlakozás, vasútállomás \\
\hline
\end{tabular}

Forrás: GLBB (2002, 10-11).

A piaci (gazdasági) folyamatok a tervezési gyakorlatban a központi helyekkel párhuzamosan jelennek meg, méghozzá a policentrikus fejlesztési modellen keresztül: szövetségi szinten 1993 óta a decentralizált koncentráció az egyik legföbb területpolitikai alapelv (Somlyódyné Pfeil 2006). A 2006-ban megfogalmazott három területfejlesztési irányelv közül a növekedésre, specializációra alapozott területfejlesztés megelözi a központi helyek rendszerében, az ellátásban gondolkodó irányelvet (Ministerkonferenz... 2006). Ennek megfelelöen fogadták el 2006-ban Branden- 
Czirfusz Márton : Ellentmondásban? Központi helyek elmélete és a városok specializációja. Tér és Társadalom 23. évf. 2009/3. 13-25. p.

burgban az „erősségek erősítése” alapelvet (Masterplan Starke Städte - Landtag Brandenburg 2006). A városfejlesztési források koncentrálása ugyan megvalósulhatna a központi helyek rendszerében a források egyes hierarchiaszintekhez való rendelésével, ám a decentralizálódás és specializálódás irányába való elmozdulás jeleként ágazatilag is priorizálták a városhálózat-fejlesztést, növekedési pólusok kijelölésén keresztül. A (központi helyek rendszerével csak részben megegyező) növekedési pólusok meghatározásától azt várják, hogy a különböző eredetủ, de csökkenő összmennyiségủ pénzügyi források felhasználása hatásosabb és irányítottabb lesz. Növekedési pólusok lettek azok a 20000 fönél népesebb városok, amelyek átlagon felüli gazdasági potenciállal rendelkeznek (azaz a gazdasági sokszínúség jegyében a tartomány számára kulcsfontosságú 16 gazdasági - zömmel ipari ágból több is képviselve van a településen), és/vagy átlagon felüli tudományos potenciáljuk van (felsőoktatási intézménnyel vagy kutatóintézettel rendelkeznek). Egyes esetekben a gazdasági munkamegosztás miatt több, egymás közelében fekvő várost soroltak egy növekedési pólushoz (Land Brandenburg 2007). Összességében tehát a brandenburgi koncepció ezen része Georges Benko fogalmait használva a technológiai pólushoz áll közel (Benko 1992). A növekedési pólusok gazdasági szempontú fejlesztéseit a településekben a telephelyfejlesztési koncepciók (Standortentwicklungskonzept) rögzítik, amelyek a városfejlesztési koncepciókhoz hasonlóan a helyzetelemzéstöl a stratégiaalkotáson keresztül a kulcsprojektek megfogalmazásáig terjedő dokumentumok.

A fentiek adják azt a hibrid, a központi helyeken keresztül a kiegyenlítődést, a növekedési pólusok révén pedig éppen a városok közötti különbségek növekedését eredményező keretfeltétel-rendszert, amelyhez az egyes településeknek saját fejlesztési terveik kidolgozásakor igazodniuk szükséges.

A tartományi és települési szint fejlesztési szempontjai közötti kapcsolatra további hatással van az integrált városfejlesztési koncepciók kidolgozását segitỏ kézikönyv, amelyet a tartomány Infrastrukturális és Területrendezési Minisztériuma (Ministerium für Infrastruktur und Raumordnung) megbízásából készített el két tervezỏ cég. A kézikönyv maga (Arbeitshilfe... 2006) határozott elmozdulást mutat a tartományi területfejlesztési alapelvek tekintetében, hiszen már címében is azt hangsúlyozza, hogy a városfejlesztést az erősségek erösítése alapelv alapján végzik. A kereteket meghatározó, hivatkozott dokumentumok között emellett különböző EU-s anyagok szerepelnek (hiszen a pénzügyi források jelentős része egyelőre az EU-tól származik). Az EU fenntartható városfejlesztési alapelvét a kézikönyv alulról, a településeken (és azok integrált és fenntartható fejlesztési koncepcióin) keresztül kapcsolja a tartományi szinthez ugyanebben a fejezetben, közvetlenül az erősségek erösítése irányelv említése után. A megoldás indokolható, hiszen a fenntarthatósági szempontok átfogóan értelmezendők, nem szúkíthetók le kizárólag a „kiválasztott” városok (növekedési pólusok) esetére; ugyanakkor vitathatatlanul összemossa a kapcsolatokat, alá-, fölé- és mellérendeltségi viszonyrendszereket a területi szintek között. Ráadásul a kézikönyv említést sem tesz a központi helyek rendszerének dokumentumáról, csökkentve annak legi- 
Czirfusz Márton : Ellentmondásban? Központi helyek elmélete és a városok specializációja.

Tér és Társadalom 23. évf. 2009/3. 13-25. $p$.

timáltságát, éppen annak felülvizsgálati időszakában (az új rendszer Berlin-Brandenburg közös területfejlesztési tervébe integrálva várhatóan 2009-ben kerül elfogadásra).

Összességében a tartományi szintủ tervezést egy egyensúlyozási folyamat jellemzi az elfogadott, érvényben levő dokumentumok, tervek és alapelveik rendszerében, utalásokkal mind a központi helyek szigorú hierarchizáltságára, mind a városok profilírozására-specializálására. Ez természetesen a városok fejlesztési stratégiáira is hatással van, ám hogy pontosan milyen szempontból, arról közvetve maguk a tervek nyủjtanak információt.

\section{Felsőfokú központok integrált városfejlesztési koncepciói}

Brandenburg tartományban a városi tervezés legfontosabb dokumentumává az utóbbi években az integrált városfejlesztési koncepció (Integrierter Stadtentwicklungskonzept, INSEK) vált, amely a magyarországi integrált városfejlesztési stratégiákhoz (IVS) nagyban hasonlító terv. Integrált szemléletmódja több dimenzióban is megnyilvánul, amelyek közül számunkra az ágazatok (tématerületeken átíveló jelleg) és a területi szintek összefogásának szempontja fontos.

Vizsgálatunkban a teljes és részleges felsőfokú központok koncepcióinak elsősorban a stratégiai fejezeteit elemezzük. Ezek a városok a következők: Potsdam (151 ezer lakos), Cottbus (103 ezer lakos), Brandenburg an der Havel (73 ezer lakos), Frankfurt an der Oder (62 ezer lakos), Eberswalde (41 ezer lakos), Neuruppin (32 ezer lakos); amelyek közül a két utóbbit az új központi helyek rendszerében feltehetően középfokú centrummá sorolják vissza (GLBB 2002; 2007). Arra vagyunk tehát kiváncsiak, hogy vajon a központi helyek elméletének jobban megfeleltethetö komplex, ellátási hangsúlyokat elötérbe helyezö, vagy egyes ágazatokat-témákat az erösségek erösitése elv alapján kiemelö szemlélet a hangsúlyosabb a városok fejlesztési alapdokumentumaiban. Természetesen a koncepciók sokkal összetettebbek tartalmukban, mint hogy csak az ellátási és gazdasági-gazdaság-fejlesztési oldalra koncentráljanak; ám mégis iránymutatásul szolgálhatnak a kérdés megválaszolásában.

A vizsgálatban az INSEK-kézikönyv vonatkozó ajánlásaiból érdemes kiindulni (Arbeitshilfe... 2006, 21). Ezek szerint a koncepciók jellemzője:

- a célok következetes levezetése és konkrét megfogalmazása,

- a fejlesztési célok koncentrálása a városfejlesztés lényegi pontjaira,

- az EU horizontális céljainak figyelembe vétele,

- minőségi és mennyiségi eredményességi ismérvek megadása,

- világos területi jövőkép (ábra) megfogalmazása a város egészére vonatkozó fejlődés megjelenítésével.

Látható, hogy a központi helyek dokumentumához való illeszkedés kritériuma nem jelenik meg az ajánlásrendszerben, a források koncentrálása (a második ponton keresztuil) viszont igen. Emiatt feltételezhetjük, hogy a tervek kevésbé foglalkoznak a város helyével a központi helyek rendszerében. Ezt a feltételezést erősítheti, hogy a városok egy része integrált város- és telephelyfejlesztési koncepciót készített, 
Czirfusz Márton : Ellentmondásban? Központi helyek elmélete és a városok specializációja. Tér és Társadalom 23. évf. 2009/3. 13-25. p.

TÉT XXIII. évf. 2009 ! 3

Ellentmondásban?

amelyben értelemszerüen a gazdasági-gazdaságfejlesztési kérdések hangsúlyosabbak egy ,egyszerü” INSEK-nél.

A városokat népességszám szerinti csökkenö sorrendben tekintjük át.

Potsdam városának koncepciója különbözik a többi városétól annyiban, hogy (legalábbis bevezetöjében) nem reagál a központi helyek rendszerére. Egy tartományi fơváros szempontjából természetesen ez nem létkérdés, hiszen felsőfokú központi szerepköre - ahogy a helyzetelemzésben ki is emelik - biztos és megkérdöjelezhetetlen, annak ellenére, hogy bizonyos területeken (kiskereskedelem, sport- és szabadidős létesítmények) Berlin közelsége miatt kevésbé jó ellátottságú. A koncepció bevezetôjében így a regionális növekedési pólusokra és a városfejlesztési kerettervre (Masterplan Starke Städte) történik utalás. A város jövökép-szlogenje „Mozgásban Potsdam 2020" ugyan dinamikára utal, de semmilyen egyediségetspecializáltságot nem sugall. A célkitüzéseket négy tematikus pont (fỏváros, tudásváros, kultúrváros és szülőváros) alá rendezték, amelyek a szándékok szerint kevésbé szektorális-ágazati, inkább integrált jellegüek. A fơvárosi célrendszer alá tartozik a felsöfokú központból adódó funkciók többsége (ilyen módon mégis utalás történik a központi helyek rendszerére), az elérhetőség javítása, de városrészi preferenciák is megjelennek a belváros kapcsolódó megújításával. A tudásváros pont elsősorban az oktatásra-képzésre koncentrál, de annak gazdasági, munkaerő-piaci következményeinek tervezése is ez alá a cél alá került. A kultúrváros célrendszerébe a kultúra mellett turisztikai és gazdasági (kultúrgazdaság) vonatkozások is bekerültek. Többek között a lakókörnyezeti megújulást, a szociális ellátórendszer fejlesztését, a városrészi adottságok és a városi identitás javítását tủzi ki célul a szülöváros pont, amely ilyen módon inkább „befelé”, a helyi lakosság ellátására irányul (Landeshauptstadt Potsdam 2007).

Ezzel szemben kifejezetten a központi helyek tartományi rendszerére reagál annak második legnagyobb városa, Cottbus stratégiája. Megállapitja, hogy a központi helyek rendszerének 1995-ös kidolgozása óta (ahol a várost felsőfokú központtá minösítették) minőségileg bővült központi szerepköre (mennyiségileg már kevésbé, hiszen a város népességszáma csökkent). A megújított beosztásban várhatóan lényegesen csökkenni fog a közép- és felsőfokú központok száma, amellyel kapcsolatosan számítanak a város szerepkörének növekedésére (mivel szükséges lesz átvállalnia bizonyos feladatokat más, „megszűnő”, amúgy is népességszámcsökkenéssel szembenézni kénytelen településektől). Másik oldalról a terv részletesen tárgyalja a központi szerepkör gazdasági vetületét: regionális növekedési pólusszerepét és következményeit. A dokumentumban ezen túl megjelenik a megélt funkciók elemzése, hiszen a város szerint a rossz elérhetőség miatt a funkciók megélésének megvalósulása alacsony. A fejlesztési alapelveknél a tanulmányban felvetett két alapelv közötti egyensúlykeresés figyelhető meg, azaz a felsőfokú központi funkciókat próbálják meg összeegyeztetni a régió adottságaival, profiljával. A városfejlesztés jövőkép-szlogenje (Cottbus 2020 - Energiával a jövőbe) részben utal a város gazdaságában az energiaipar jelentöségére. A részletezésböl viszont az is 
Czirfusz Márton : Ellentmondásban? Központi helyek elmélete és a városok specializációja.

Tér és Társadalom 23. évf. 2009/3. 13-25. $p$.

kiderül, hogy a városfejlesztést is kifejezetten erről az oldalról közelítik meg: csak a gazdaság stabilizálásával lehet társadalmi, kulturális és városépítészeti minőségi változásokat elérni. A célkitüzéseket három fö területre (gazdasági tér, jövöbeli tér, élettér) összpontosítják. Ezek közül az első, a gazdasági tér a gazdaság, ezen belül is az ipar fejlesztésére vonatkozik. A dokumentumban keverednek a város gazdaságát elsődlegesen meghatározó szekunder szektor és a felsőfokú központ jellegböl adódó, elsösorban a tercier szektor fejlesztését elöirányzó elképzelések. A második pont - összekötve a két elöbbi szempontot - a képzésre és a kutatásra összpontosit. A harmadik csoportba tartozó, a városi élettérre vonatkozó tervek a kultúra, a sport és a turizmus ágazataihoz kapcsolódnak, ilyen módon kevésbé jelentik a felsőfokú központi szerepkör erősítését (Stadtverwaltung Cottbus 2007).

Brandenburg a tartomány harmadik legnagyobb városa. Integrált városfejlesztési koncepciójának helyzetértékelő része megállapítja, hogy az utóbbi években minden felsőfokú intézményt kiépítettek, csak a kiskereskedelmi kínálat terén vannak még kisebb elmaradások. A dokumentum - Cottbushoz hasonlóan - megkülönbözteti egymástól a felsőfokú központ jellegből adódó kijelölt és a lakosság által megélt funkciókat. Megállapítja, hogy - ugyan az utóbbi években minden felsőfokú intézményt kiépitettek, tehát különösebb elmaradások a kiskereskedelmi kínálat kivételével nincsenek - a felmérések alapján a lakosság a jelenleginél is több funkciót szeretne a városban tudni. A jövőkép-szlogen - talán a funkcionális gazdagság miatt - az inkább semmitmondó „A város a folyóban” lett, amely ugyan a határozott névelövel az egyediséget sugallja, valójában azonban a tartomány nagyobb városai közül el-vétve találunk olyat, amelyik nem vízparton fekszik. Ennek megfelelően a fejlesztési alapelvek is inkább átfogó, horizontális jellegủek (esélyegyenlőség, fenntarthatóság, integráltság, participáció stb.), mintsem határozott profilírozás irányába hatnának. A stratégiai fejlesztési célok tematikus csoportosításánál ugyan részletesebben is előkerülhettek volna a felsőfokú központ szerepéből adódó ellátási feladatok, ám ezeket a dokumentum egy külön csoportba (Centrum-Régió-Szolgáltatások) foglalta össze. A központi helyek hierarchiájában való gondolkodás megnyilvánul abban is, hogy a kulcsintézkedéseket az ágazatok mellett ezek alapján csoportosítják: elkülönítenek általános jellegủ, regionális / felsőfokú központi hatású és a városi szinthez köthető intézkedéseket (Stadt Brandenburg... 2006).

Frankfurt an der Oder a tartomány legkisebb felsőfokú központja lesz a megújított központi helyek rendszerében. Ugyanakkor a stratégia bevezetőjében ezt a szerepkört nem említik, csak a város regionális növekedési pólus-szerepét, valamint a városfejlesztésben a különbözỏ adottságokkal rendelkező városrészekre való koncentrálást. Frankfurt ennek ellenére nem integrált település- és telephely-fejlesztési stratégiát készített, hiszen ez utóbbi már 2006-ban elfogadásra került egy, a közeli Eisenhüttenstadttal közösen megirt dokumentumban. A városfejlesztési stratégiában ugyanakkor a gazdaság helyzetelemzésénél a tartományi szintủ, növekedési pólusokat meghatározó dokumentumban a városnak „kiutalt” ágazatokat veszik sorra (ez a rendező elv), majd egészítik ki az ott nem emlitett, de a város számára jelentős ágazatok helyzetének és lehetöségeinek elemzésével; némileg ellenében hatva a specia- 
Czirfusz Márton : Ellentmondásban? Központi helyek elmélete és a városok specializációja. Tér és Társadalom 23. évf. 2009/3. 13-25. p.

lizálódásnak. A város jövőképe meghatározásának elméleti bevezetőjében a települések egyediségének hangsúlyozását emelik ki, vagyis a központi helyek egységesító szemléletével szemben a profilírozás mellett foglalnak állást, ugyanakkor kiemelik a magasabb területi szintủ tervekhez való illeszkedés szükségességét is. Ezek alapján döntöttek végül a „Frankfurt (Oder) egyetemi város - ötletek piactere egy egységesült Európában" szlogen mellett, amely véleményük szerint a város egyedülállóságát mutatja be abban, hogy egyetemmel rendelkező határon átnyúló szerepkörü felsőfokú központról van szó. Pusztán Brandenburg tartományt nézve ez az egyediség természetesen igaz (hiszen Frankfurt az egyetlen határközeli felsőfokú központ), ám országos viszonylatban nem, hiszen a felsőfokú központok mindenképp egyetemmel rendelkező települések, amelyek közül több is a határ közelében fekszik. A jövőkép négy komponense közül az első kifejezetten a felsőfokú központi (közte a határon átnyúló) szerepkör erősítését célozza meg. A második pont a gazdaságfejlesztési elképzeléseket mutatja be, a kiemelkedő szerepü ágazatok (tartományi szintű tervekből is adódó) erősítése mellett, ennek ellentmondva a sokszínủség növelését is hangsúlyozva. A város képzési és kulturális szerepkörét kívánja erősíteni a harmadik pont, amely elsősorban az oktatás-képzés horizontális beágyazódását (hálózatosodás, gazdasággal való kapcsolatok kiépítése-javítása) erősítené. A negyedik pont az életminőség javitását és a város attraktivitásának növelését tüzi ki célul, amely így a turizmustól a szociális ellátórendszer felsőfokú központ jellegböl adódó funkcióin keresztül az épületek felújitásáig tág területet fog át (Stadtverwaltung Frankfurt... 2007).

Eberswalde stratégiájának példája jól mutatja, hogy a tervdokumentumok milyen módon reagálhatnak a megváltozó keretfeltételekre (jelen esetben az átdolgozott központi helyek rendszerére). Ennek egyik vonulata a középfokúvá visszasorolandó központ részleges felsőfokú központ-voltának erősítése a dokumentumban. Ilyen módon Brandenburghoz hasonlóan (a hasonlóság hátterében az azonos, tervkészítésben közreműködő cég állhat) bemutatják, hogy a megélt funkcionális vonzáskörzet sokkal nagyobb annál, mint amelyet a középfokú központ tervében leirtak, így próbálva ellenében hatni a tartományi szintul elképzeléseknek. A jövőkép-szlogen, eltérỏen a többi várostól, nem tematikusan meghatározott, hanem a múlt és a jövő összekapcsolásán alapul. (Eberswalde macht mehr! Tradition trifft Moderne. Eberswalde többre képes! A hagyomány találkozik a modernitással.) A fejlesztési alapelvek hat pontja közül három részben vagy egészében kapcsolható a tartományi fejlesztési dokumentumokhoz: erösíteni és továbbfejleszteni kívánják a meglévő városi funkciókat, ezt regionális kontextusba helyezve a környező települések ellátására is gondolva. Ugyanakkor a priorizálás (erősségek erősítése) és a területi koncentrálás fogalma is előkerül az ellátás kapcsán, ám inkább a településrészek közötti funkciómegosztás vonatkozásában. A tematikus súlypontok között az ágazatok viszonylag nagy hányada elökerül a képzéstól a kultúrán át a turizmusig; a központi helyekhez (és a város középfokú/részleges felsőfokú szerepkörhöz) leginkább a városszerkezet-lakás-városrégió pont kapcsolódik. A tervdokumentumokra való utalás másik vonulata a gazdasági tartalom előtérbe helyezése, a város is integrált 
Czirfusz Márton : Ellentmondásban? Központi helyek elmélete és a városok specializációja.

Tér és Társadalom 23. évf. 2009/3. 13-25. $p$.

22 Czirfusz Márton

TÉT XXIII. évf. 2009 — 3

város- és telephely- (gazdaság)fejlesztési koncepciót írt. Ezáltal hangsúlyos célként jelenik meg a gazdasági profil szélesítése, új gazdasági ágazatok meghonosítása. Ezt erősíti, hogy a tematikus célok között is az első a gazdaság-munka-képzés hármast fogja össze (Stadt Eberswalde 2008).

Neuruppin jövőképét a „Város-Kultúra-Víz 2015” szlogennel fejezik ki, amelyben a felsőfokú központok által ellátandó funkciók közül egyértelmúen a kultúra válik hangsúlyossá, annak ellenére, hogy a dokumentum maga integrált jellegủ városés gazdaságfejlesztési koncepció. A részletes jövőkép (külső cég által a város megrendelésére készített!) értékelése a területi elhelyezkedésre való erős támaszkodást emeli ki, ami egyrészt egybevág a központi helyek rendszerének figyelembevételével (a helyzetértékelés a központi funkciókból indul ki), másrészt megjelenik a fejlesztési alapvetések sorában is (meglévő funkciók és központi szerepkörü intézmények biztosítása-megerősítése). A konkrét stratégiai fejlesztési célok középpontjában az előbbiekkel összhangban az elérhetőség és a földrajzi helyzetböl adódó következmények állnak (ugyan a hangsúlyokat az egyediségek kidomboritására és a policentrizmusra helyezik); az ágazatok közül a gazdaság mellett a kultúra (nem elsősorban a kínálat megfelelése a felsőfokú központ szintjének, hanem a kultúra révén a helyi identitás javítása), a turizmus és a képzés (a központi helyek dokumentumával szemben szakképzési, gazdasággal való együttmüködési hangsúllyal) jelenik meg. A felsőfokú funkciók közül a szolgáltatások (szolgáltatások diverzifikálása, amely egyéb, fenti ágazatokat is érint, például a kultúrát) áttételesen, a belváros fejlesztésének területi célján belül kerülnek említésre (Fontanestadt Neuruppin 2007).

\section{Összefoglalás}

A tanulmány a brandenburgi felsőfokú központok integrált városfejlesztési stratégiáinak elemzésén keresztül arra a kérdésre kereste a választ, hogy vajon ténylegesen ellentmondások feszülnek-e a központi helyek elméletének szigorú hierarchizáló és homogenizáló jellege és a városverseny révén szükséges profilírozási-specializálódási szükségszerúségek között. A valójában két eltérő tervezési megközelítést megtestesítő alapelv a gyakorlatban, amint a tervek elemzése rámutatott, közös nevezöre hozható (erre talán leginkább Frankfurt példája idézhetó), mégha esetlegesen konfúz módon is.

A városok integrált fejlesztési koncepciói - szemben sok magyarországi integrált városfejlesztési stratégiával - általában a helyzetértékelésre épülő megalapozott jövőképet és stratégiát határoznak meg maguk számára. Emellett - főleg a megújuló központi helyek rendszerében nagy valószínűséggel középfokú centrummá visszasorolandó települések esetében - a dokumentumok kifelé erösséget mutató, a város pozícióját a tartományban megerósítő szemléletet is sugallnak, például a helyzetértékelésben az ellátás funkcióbővülésre utaló javulásának bemutatásával. Eberswalde példája pedig jól mutatja, hogy a tervdokumentumban a központi helyekhez nem közvetlenül kötődő gazdaság hangsúlyosabbá tételével lehet a központi helyek 
Czirfusz Márton : Ellentmondásban? Központi helyek elmélete és a városok specializációja. Tér és Társadalom 23. évf. 2009/3. 13-25. p.

rendszerében a város számára kedvezőtlen változásból „menekülési utat” találni. A központi funkciókból adódó ellátási feladatok tervben való megjelenitésére a városok különbözö megoldásokat alkalmaztak: ezeket egyrészt megjeleníthették külön cél alá rendezve (Brandenburg), vagy „,szétdarabolva” (Potsdam, Cottbus). Utóbbi megoldás esetén a dokumentumok a témák-ágazatok közötti összefüggést hangsúlyozzák, ami ugyanakkor a központi szerepkörök strukturálását is eredményezheti, például külön célcsoportban lehet megjeleníteni az inkább kifelé mutató kapcsolatokat előtérbe helyező képzést-oktatást, valamint az inkább a helyi lakosságra irányuló és elemeiben városrészek között is differenciálandó szociális ellátórendszert.

A városfejlesztési dokumentumok megírása a tartományban összekapcsolódik egy, a várost meghatározó jövőkép-szlogen (általában a helyi szereplők bevonásával végzett) megfogalmazásával. Ezek a rövid mondatok markánsan közvetíthetik a városok állásfoglalását a specializáció és a homogenizálódásra utaló központi szerepkörön alapuló ellátás tekintetében. A semmitmondóbbak (azaz általános, az ország rengeteg városában ugyanúgy használható - Potsdam, Brandenburg) mellett bizonyos ágazatokat kiemelő (Frankfurt, Neuruppin; illetve gazdasági oldalról Cottbus), így a specializációt a tervek szintjén erösitő szlogenek szintúgy elöfordulnak.

Összességében a tanulmány rámutatott arra, hogy két, egymástól különböző tervezési elmélet a gyakorlatban mind felsőbb (tartományi, országos), mind alsóbb (városi) szinten jelen lehet egymással párhuzamosan. Az viszont, hogy ez a kettősség nem hátráltatja-e a tervezést és a városfejlesztés megvalósítását egy önálló vizsgálatot igényel.

\section{Jegyzetek}

${ }^{1}$ A tanulmány alapkérdései az MTA RKK Budapesti Osztályán a Nemzeti Fejlesztési és Gazdasági Minisztérium megbizásából végzett Javaslatok az Integrált Városfejlesztési Stratégiák készitését segító Kézikönyv módositására hazai IVS-ek elemzése és külföldi tapasztalatok alapján címủ kutatás során fogalmazódtak meg; részben felhasználja a kutatócsoport zárótanulmányban leírt eredményeit.

2 A társadalmi folyamatok objektiv tervezhetőségének doxáját a társadalomfơldrajzban (a háttérről lásd Kitchin 2006) és általában a társadalomtudományokban (pl. Bourdieu 1986) tudományelméleti alapokon eredményesen támadták a hatvanas évek végétől.

\section{Irodalom}

Arbeitshilfe zur Erstellung von Integrierten Stadtentwicklungskonzepten INSEK auf Grundlage des „Masterplan Starke Städte" des Landes Brandenburg. (2006) complan-DV, Brandenburg.

Beluszky P. (1985) Néhány gondolat az Országos Településhálózat-fejlesztési Koncepció felülvizsgálatakor. Területi Kutatások. 7. 19-38. o.

Beluszky P.-Gyóri R. (2004) Fel is út, le is út... (Városaink településhierarchiában elfoglalt pozícióinak változásai a 20. században.) - Tér és Társadalom. 1. 1-41. o.

Benko, G. (1992) Technológiai parkok és technopoliszok földrajza. MTA Regionális Kutatások Központja, Budapest.

Blotevogel, H-H. (2005) Neuformulierung des Zentrale-Orte-Konzepts. Kurzfassung eines Vortrags im Rahmen einer Fachtagung des Ministeriums des Innem und für Sport, Oberste Landesplanungsbehörde, am 14.07.2005 in Budenheim bei Mainz. Kézirat. 
Czirfusz Márton : Ellentmondásban? Központi helyek elmélete és a városok specializációja.

Tér és Társadalom 23. évf. 2009/3. 13-25. p.

Bourdieu, P. (1986) Social space and symbolic power. - Bourdieu, P. (1990) In Other Words. Essays Towards a Reflexive Sociology. Polity Press, Cambridge, 123-139. o.

European Commission (1999) European Spatial Development Perspective. Towards Balanced and Sustainable Development of the Territory of the European Union. Office for Official Publications of the European Communities, Luxembourg.

Faragó L. (2007) Térstruktúra: térideák és megvalósításuk a településhálózat-fejlesztésben. - Tér és Társadalom. 4. 21-38. o.

Fontanestadt Neuruppin (2007) "NeuruppinStrategie 2020« Gesamtkonzept 2007 [Integriertes Stadtentwicklungskonzept und Standortentwicklungskozept]. Neuruppin.

GLBB (2002) Landesentwicklungplan Brandenburg. Zentralörtliche Gliederung. Gemeinsame Landesplanungsabteilung Berlin-Brandenburg, Potsdam.

GLBB (2007) Landesentwicklungplan Berlin-Brandenburg (LEP B-B). Gemeinsame Landesplanungsabteilung Berlin-Brandenburg, Potsdam.

Johnston, R.J.-Sidaway, J.D. (2004) Geography \& Geographers. Anglo-American Human Geography since 1945. Sixth Edition. Arnold, London.

Kitchin, R. (2006) Positivistic Geographies and Spatial Science. - Aitken, S.-Valentine, G. (eds.) Approaches to Human Geography. Sage Publications, London-Thousand Oaks-New Delhi. 20-29. o.

Koschny, R.-P.-Mensing, K.-von Rohr, G.H.-G. (1998) Weiterentwicklung der Zentrenstruktur in Verdichtungsräumen. Das Beispiel Nordraum Hannover. - Standort-Zeitschrift für Angewandte Geographie. 2. 12-20. 0 .

Land Brandenburg (2007) Operationelles Programm des Landes Brandenburg für den Europäischen Fonds für regionale Entwicklung (EFRE) in der Förderperiode 2007-2013. Ziel „Konvergenz". Land Brandenburg, Potsdam.

Landeshauptstadt Potsdam (2007) Integriertes Stadtentwicklungskonzept. Stand 23. November 2007. Postdam.

Landtag Brandenburg (2006) Starke Städte - Masterplan Stadtumbau. Stand 09.01.2006. Bericht des Ministers für Infrastruktur und Raumordnung, Postdam.

Markusen, A.-Schrock, G. (2006) The Distinctive City: Divergent Patterns in Growth, Hierarchy and Specialisation. - Urban Studies. 8. 1301-1323. o.

Meijers, E.-Romein, A. (2003) Realizing Potential: Building Regional Organizing Capacity in Polycentric Urban Regions. - European Urban and Regional Studies. 10. 173-186. o.

Ministerkonferenz für Raumordnung (2006) Leitbilder und Handlungsstrategien für die Raumentwicklung in Deutschland. Geschäftsstelle der Ministerkonferenz für Raumordnung im Bundesministerium für Verkehr, Bau und Stadtentwicklung, Berlin.

MTA RKK-VÁTI (2008) A magyar településhálózat helyzete és távlatai. Országos Településhálózatfejlesztési Koncepció szakmai megalapozása. Aktualizált Munkaváltozat 3.1. 2008. november 5. MTA RKK-VÁTI, Pécs-Budapest.

Pálné Kovács I. (2008) Az új várospolitika kormányzási filozófiája. - Tér és Társadalom. 1. 45-57. o.

Seelig, S. (2007) Stadtumbau und Aufwertung. Thesen zur Bewertung der Umsetzung des Programmteils Aufwertung im ,Stadtumbau Ost" - Eine Untersuchung am Beispiel der Hansestadt Greifswald. Graue Reihe des Instituts für Stadt- und Regionalplanung. 4. Technische Universität, Berlin.

Somlyódyné Pfeil E. (2006) Nemzetállami várospolitikák és az Európai Unió policentrizmus koncepciója. Tér és Társadalom. 4. 31-47. o.

Somlyódyné Pfeil E. (2008) A városi térségek a közigazgatási struktúra és a ,governance” keresztmetszetében. - Tér és Társadalom. 1. 27-43.

Stadt Brandenburg an der Havel (2006) Masterplan Stadt Brandenburg an der Havel. Brandenburg an der Havel.

Stadt Eberswalde (2008) »Strategie Eberswalde 2020« Gesamtkonzept 2007. Integriertes Stadtentwicklungskonzept (INSEK) und Wirtschafts-Standortentwicklungskonzept. Eberswalde.

Stadtverwaltung Cottbus (2007) Integrierter Stadtentwicklungskonzept. Cottbus 2020 - , mit Energie in die Zukunft". Cottbus.

Stadtverwaltung Frankfurt (Oder) (2007) Integriertes Stadtentwicklungskonzept (INSEK) Frankfurt (Oder). Abteilung Stadtentwicklung, Frankfurt (Oder).

Stiens, G.--Pick, D. (1998) Die Zentrale-Orte-Systeme der Bundesländer. Aktuelle Strukturen und Steuerungsfunktionen. - Raumforschung und Raumordmung. 5-6. 421-434. o. 
Czirfusz Márton : Ellentmondásban? Központi helyek elmélete és a városok specializációja.

Tér és Társadalom 23. évf. 2009/3. 13-25. p.

TÉT XXIII. évf. 2009 a 3

Ellentmondásban?

25

\section{CENTRAL PLACE THEORY AND THE SPECIALISATION OF CITIES: A CONTRADICTION?}

\section{MÁRTON CZIRFUSZ}

The paper scrutinises the contradiction between two theoretical approaches in planning: the strictly hierarchical central place theory and certain specialisation theories (such as polycentrism and growth poles), supported with the case study of the State of Brandenburg, Germany. As presented in the paper the central place theory still has a deterministic role in regional policy and planning in Brandenburg, which means that the planning approach has not gone through substantial transformation compared to the socialist practice dominating regional planning.

During the 1990 s, more timely theories also emerged in planning practice on the state level defining growth poles. This theory and the related planning policy focus on the specific properties of cities, using them as resources in the competition of places.

These approaches equally manifest themselves in the integrated urban development strategies of the six higher-order cities of Brandenburg. In the paper it is concluded that these strategies combine the necessity of providing services demanded by central place theory with the need to establish, maintain and most of all strengthen the unique characteristics of cities, this way making them competitive in the globalised socio-economic context.

To sum up, different planning theories are present on the same and on different levels (state, region, city) as well. Theoretically they are in contradiction, but they seem to coexist well in the practice. 